\title{
Campaigning consultation websites for teenagers: Study on sobatmu.com
}

\author{
Ira Mirawati ${ }^{1}$, Kismiyati El Karimah ${ }^{2}$ \\ \{ira.mirawati@unpad.ac.id, kismiyati@unpad.ac.id \} \\ ${ }^{1,2}$ Faculty of Communication Science Universitas Padjadjaran, Indonesia
}

\begin{abstract}
Previous research from Communication Management Department Faculty of Communication Science, Universitas Padjadjaran, entitled Development of Online Consultation Media as an Effort to Overcome Problems in West Java succeeded in developing www.sobatmu.com, a youth consultation website. At the end of 2014, the website was ready to be used. For the teenager in West Java know about this online consultation service, proper campaign strategy is needed and can move teens to use this website as a means of consultation. The research, which was designed using action research method, was aimed at finding an appropriate campaign model for socializing online consultation programs. Research carried out by practicing various campaign tools, the next survey was conducted to visitors to gather information about the source of their information about this consulting service.The results of the research show the use of conventional media in practice that is not broad reach, requires printing costs so that campaign becomes more expensive, and the audience does not act directly to access the website. Meanwhile through counseling, limited outreach, requiring fees for rental premises, cleaning service officers, event promotions, and other costs that make activities require no small amount of funds. Nevertheless, audiences act immediately and have long-term effects, because they are motivated and motivated to use existing consulting services. On the other hand, the use of digital media for the means of socializing online consulting services is the cheapest thing to do, because the applications and social media available can be accessed free of charge. In addition, digital media has a broad reach and audiences act directly.To get massive effects, which are many and broad, but have deeper and longer effects, the suggested collaboration is the use of digital media and extension.
\end{abstract}

Keywords: campaign, online consultation, www.sobatmu.com, adolescent problems

\section{Introduction}

The rapid development of communication and information technology has become a way of developing various online consulting services. Current online consultation can be done using a mobile application, one of which is intended for teenagers (Mirawati, Sugiana, \& Wirakusumah, 2019)

The results of previous research regarding the Development of Online Consultation Media as an Effort to Address Youth Problems shows that problems faced by adolescents in Bandung include friendship, romance, family problems, and financial problems (Mirawati, 2016). In general, adolescents tell their problems to their friends, not to their family or their teacher. Most of them have posted their problems on social media, just to release the pressure, without expecting feedback from their friends or followers. Almost all respondents of this research are interested in trying if there is an online consulting service. They hope, even though online, consultations can still be carried out personally without appearing in a realm that can be read by others, and don't 
let their problems be told to the public, even if their names are disguised. In addition, respondents suggested that the online consultation media use a name that is close to the lives of teenagers, not a formal name that reflects the institution.Based on this descriptive information, Mirawati and her team in Communication Management Department Faculty of Communication Science, Universitas Padjadjaran then developed www.sobatmu .com as an online consultation media for teenagers. Sobatmu is an acronym for "Sahabat Obrol Atasi Masalahmu" which mean friends of chat to overcome your problems". This website is designed with an attractive display, icon, and bright background colors. Consultants for this website are experienced lecturers in the field of youth problems whose profiles are displayed in the website. The following is the appearance of the website and the services it contains:

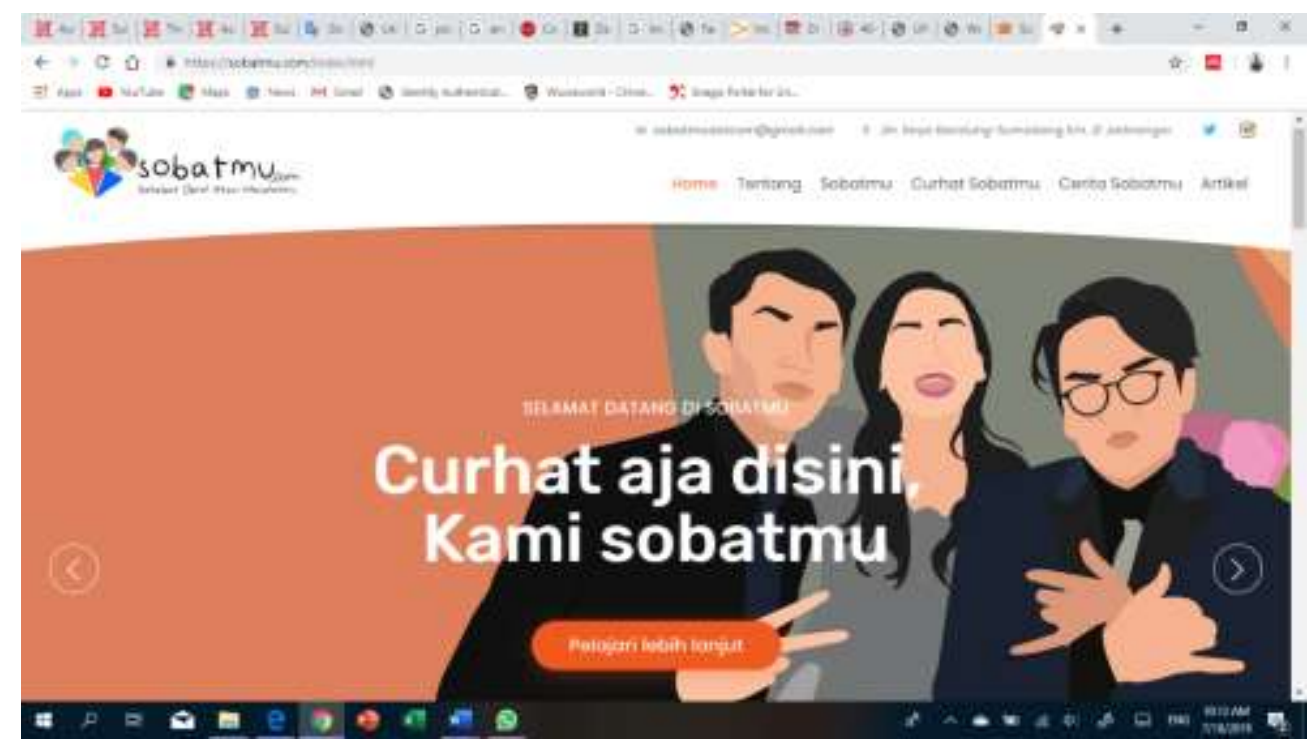

Fig 1. Homepage www.sobatmu.com 


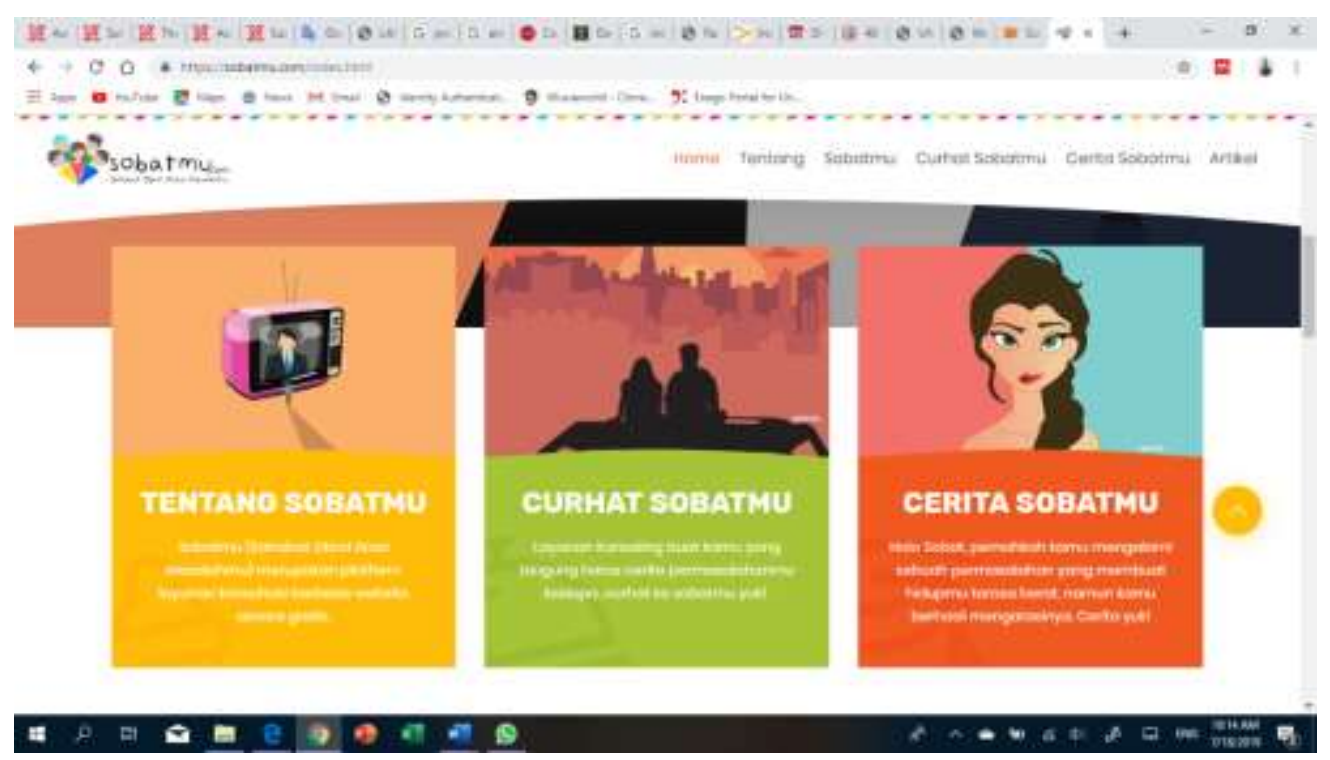

Fig 2. services in www.sobatmu.com

Currently, www.sobatmu.com has been completed and is being tested for use. This website is ready to campaign. Through this research, the research team tried to test various forms of socialization and campaigns. It is hoped, through this research, it will be known how the form of socialization that most generates hits (visits) on the website and also the form of socialization that most encourages adolescents to want to use online consultation services provided by www.sobatmu.com.

By adopting the website rating system proposed by CNET Builder [1], the assessment is carried out on the following aspects:1. Usability, it is the ease of visitors to find ways to use the website effectively 2 . Navigation system is easy to understand, therefor visitors do not have to ask other parties how to access a menu on the website 3 . Attractive graphic design both visually and typographically. In this case the structure includes the placement of website content such as headers, footers, navigation menus, and ad blocks. Including, the structure of placement on each page so that visitors are not confused with, for example, a menu that moves. Design certainly can not be separated from the selection of colors, placement of website logos and fonts that used consistently on every page. therefor visitors do not feel moved to other websites.4. Content or useful website content, whether the website content is able to provide answers to the needs of visitors. These needs can be cognitive, affective, or psychomotor. For the cognitive realm of knowledge, for affective it can be in the form of likes or dislikes of an object being discussed, and for the psychomotor aspect is how website content can teach skills or can guide audiences to take certain actions. Examples that arrive at the psychomotor aspect are online shop websites that can provide purchasing services via the internet to be done right away by visitors.5. Loading time, Loading time is the time required for a website to open the contents of the website. Besides being influenced by the speed of incoming and outgoing data data on the internet network, the length of loading time is 
also influenced by the contents of the website which includes menus and images. The larger the image size, the longer the loading time will be required. Another factor is the capacity of the server that holds the website data and the number of visitors who are currently accessing it.6. Admin response, for websites that require admin in serving visitors, then the speed of response from the admin is one of the things that can affect the assessment or satisfaction of visitors to the website. Examples of websites that require a quick response from the admin are complaint websites such as the Lapor! (www.lapor.go.id) Belonging to Bandung City Government [2], or consultation website such as klikdokter.com [3], including sobatmu.com.

\section{Method}

This research uses action research approach. the design was made so that when conducting research, the research team also took actions that changed the community to change for the better [3]. in this research, when measuring which method of campaign is most appropriate to reach the audience, namely adolescents, at the same time the researcher also conveys information and persuades students to utilize sobatmu.com in solving their problems.

\section{Result and Discussion}

By using a post test only control group design research design conducted on 30 respondents www.sobatmu.com users. The detailed questions include the following aspects:

Table 1. Questions in website product research

\begin{tabular}{llll}
\hline No. & Indicator & Questions Number & Total \\
\hline 1 & Layout & $1,2,3,4,5,6$ & 4 items \\
2 & Content & $7,8,9,10$ & 5 items \\
3 & Admin & 11,12 & 2 items \\
& Response & - & \\
\hline
\end{tabular}

These questions are: 1) the ease of remembering the name of the website, 2) the attractiveness of the website logo, 3) the color composition, 4) the use of letters, 5) the suitability of the menu, 6) the ease of signing up and logging in, 7) the layout, 8) use of images or illustrations, 9) usefulness of website content, 10) writing style and language, 11) admin responsiveness, 12) usefulness of consulting services provided.

Questionnaires were distributed and filled using offline or online, i.e. sent via their respective personal e-mails. From the tabulations conducted on the contents of the questionnaire, quantitatively the following data were obtained:

Table 2. Recapitulation of respondents' answers to product research

\begin{tabular}{llll}
\hline No & Indicators & Total score & category \\
\hline 1 & Website names are easy to remember and attractive & 4,16 & Excellent
\end{tabular}




\begin{tabular}{llll}
2 & Website names are easy to remember and attractive & 3.7 & Good \\
3 & The attractiveness of colour composition & 3,8 & Good \\
4 & Layout suitability & 3,6 & Good \\
5 & Figure/ illustration attractivensess & 3,6 & Good \\
6 & Suitability and attractiveness of font use & 3,9 & Good \\
7 & The accuracy of the menu facilities & 4.0 & Good \\
8 & Ease of signing up and logging in on this website & 3,5 & Good \\
9 & The usefulness of the articles on the "www.sobatmu.com" page. & 4,2 & Excellent \\
10 & Suitability and attractiveness of writing style & 4,1 & Excellent \\
11 & Admin report & 4,3 & Excellent \\
12 & Utilization of admin answers to the consulting services available & 4,1 & Excellent \\
\hline
\end{tabular}

The categorization is carried out by dividing the results into 4 criteria, because the option in the questionnaire, the range of research answers is $1-5$. These criteria are:

$$
\begin{array}{ll}
1-2 & : \text { Bad } \\
2,1-3 & : \text { Not Good } \\
3.1-4 & : \text { Good } \\
4.1-5 & : \text { Excellent }
\end{array}
$$

Table 3. total score to the question about layout

\begin{tabular}{llll}
\hline No & Indicators & Total score & category \\
\hline 1 & Website names are easy to remember and attractive & 4,16 & Excellent \\
2 & Website names are easy to remember and attractive & 3.7 & Good \\
3 & The attractiveness of colour composition & 3,8 & Good \\
4 & Layout suitability & 3,6 & Good \\
5 & Figure/ illustration attractivensess & 3,6 & Good \\
6 & Suitability and attractiveness of font use & 3,9 & Good \\
& Means & 3,79 & Good \\
\hline
\end{tabular}

Table 4. total score to the question about content

\begin{tabular}{llll}
\hline No & Indicators & Total score & category \\
\hline 7 & The accuracy of the menu facilities & 4.0 & Good \\
8 & Ease of signing up and logging in on this website & 3,5 & Good \\
9 & The usefulness of the articles on the "www.sobatmu.com" page. & 4,2 & Excellent \\
10 & Suitability and attractiveness of writing style & 4,1 & Excellent
\end{tabular}


Of all the existing criteria, the response of the admin is the highest to get a rating from the respondent, which is 4.2 or very good. Admin is considered fast in providing responses and answers given to answer their problems.

Admin ease in providing answers because of the system redirect from the website to each consultant's email. So, as soon as a question comes in, the question will go directly to the consultant's email. Because the average consultant already uses the push mail application on their respective smartphones, they can answer these questions directly without opening a website.

Table 5. total score to the question about Admin Response

\begin{tabular}{lllc}
\hline No & Indicators & Total score & category \\
\hline 11 & Admin report & 4,3 & Excellent \\
12 & $\begin{array}{l}\text { Utilization of admin answers to the consulting services available } \\
\text { at www.sobatmu.com }\end{array}$ & 4,1 & Excellent \\
\hline
\end{tabular}




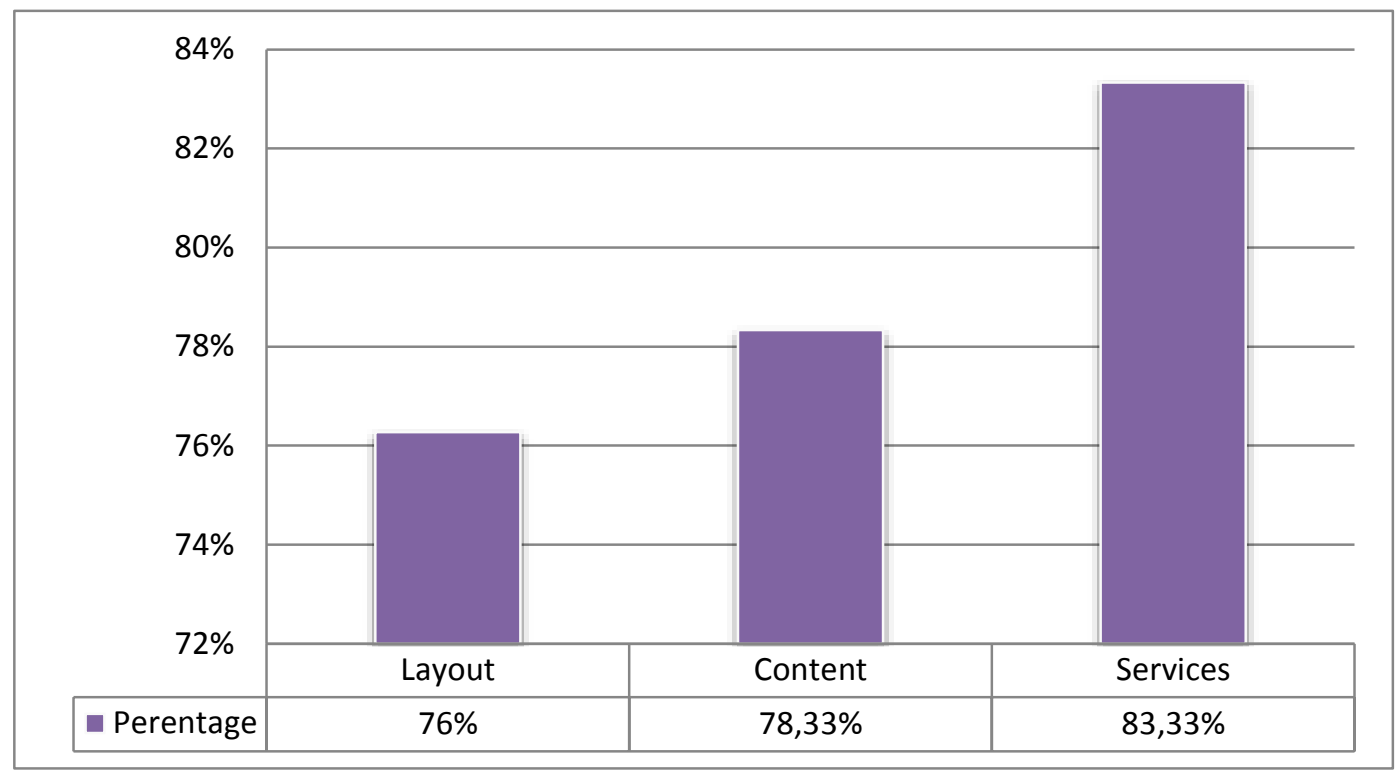

In addition to getting data on audience responses to sobatmu.com, this research has also conducted experiments to socialize this online consulting service using conventional marketing, digital marketing, and promotional and counseling events. Action were carried out by involving students of class C 2015 from Communication Managemet Department Faculty of Communication Universitas Padjadjaran. In each type of field Action conducted, be it conventional marketing, digital marketing, as well as events and promotions, there are four objectives to be achieved. The goal is to introduce www.sobatmu.com and the services that are in it, increase traffic or audience visits to this website, and invite audiences who are teenagers to consult their problems through sobatmu.com.

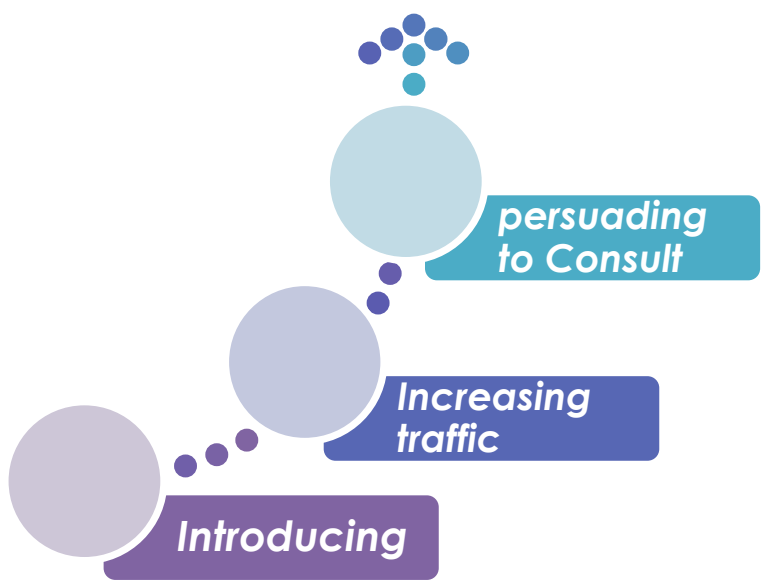

Fig 3. another goals of action research www.sobatmu.com 
Conventional marketing is carried out by printing various promotion tools which include banners, stickers, brochures, and posters. Because the location of the experiment was in Jatinangor, banners were installed at the gate of Universitas Padjadjaran Jatinangor and in front of Jatinangor 1 High School. Both of these places are considered to be the two places that represent the place for teenagers passing by in Jatinangor.

In addition to the banners, they also produce stickers that are distributed in front of Jatinangor Town Square, in various snacks, and other places visited by teenagers. The brochure is the same way, it's just that the distribution is in a crowd where the location is different from the distribution of stickers. For posters, we printed around 50 brochures and attach them to each faculty in Unpad, as well as at ITB, Ikopin, and schools in Jatinangor.

After that, two weeks later, users who had already been registered filled the questionnaires for this research.

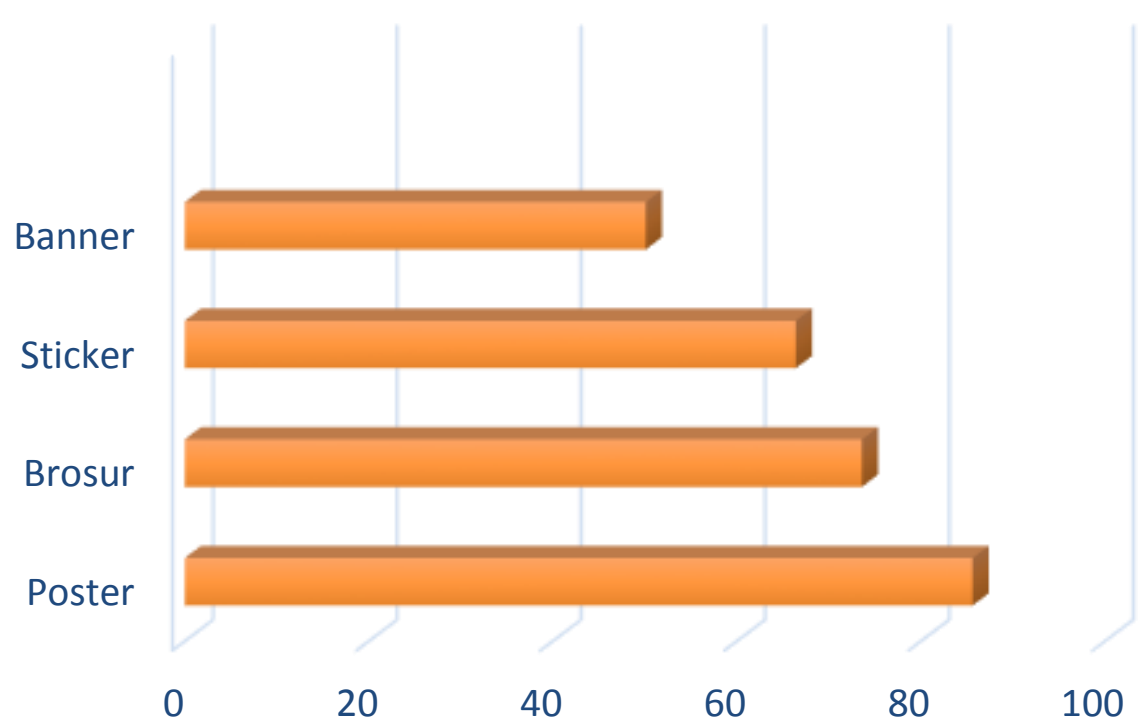

Fig. 4 Conventional marketing results

For social media, teens access sobatmu.com after seeing socialization on the following social media: 


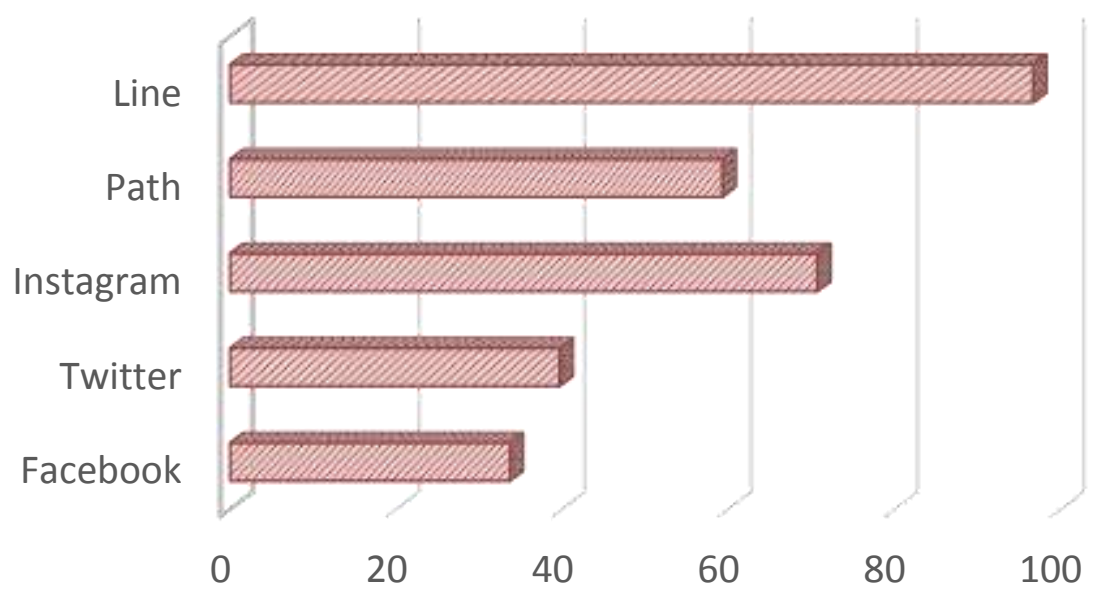

Fig. 4 Digital marketing results

The student team conducting socialization using digital media created accounts on Facebook, Twitter, Instagram, Path and Line. It turns out that many are accessing after knowing through the line. At present, the line is indeed the most widely used application by teenagers, especially students. They create groups on line to exchange information about lectures and organizations. Line is preferred by teens because it can send stickers that are creative emoticons that can express their feelings compared to a series of words that are considered boring.

For socialization through events/coaching sessiona, there are two groups that conduct the action, namely socialization to students of Al Ma'soem Rancaekek High School 3 classes and socialization to the association of high school Osis leaders in Jatinangor. Although targeting a limited number of groups, it is not mass, but the implementation of the event is able to attract participants who are not only look the website but then register to become members and conduct consultations through sobatmu.com. Even the number visitor who register because they know this counseling service from digital media is greater in number than those who register because they know from conventional marketing. Here is the comparison:

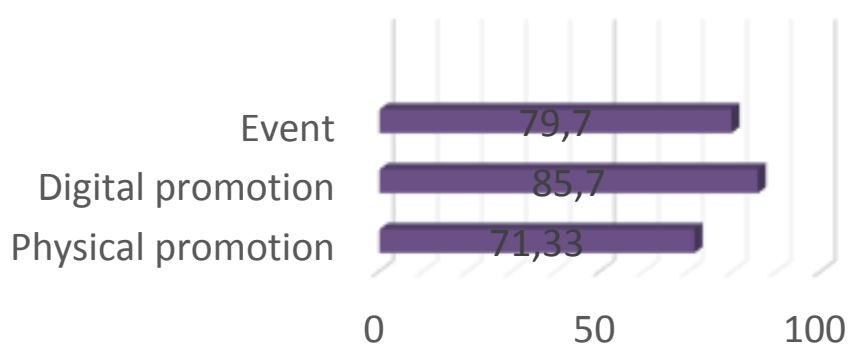

Fig4. Comparison 3 medias in campaign 
From the analysis of hits or visits that go to the website sobatmu.com. From the average visit of 30 hits per day, the number of visits will surge when the digital marketing team posts on one social media. Usually, when posting your friend's article link on line for example, the number of visitors will jump to 150 s.d. 200 hits per day, when combined all social media can be used up to 300 hits.

Visitors who access because of information from social media are visitors who only "stop by" to read articles whose links are given on social media. Likewise with those who know your friend from conventional marketing. Conversely, those who access it after receiving counseling, will usually access the site and register as a member and consult their problems.

In the following, the researchers describe the comparison of the types of socialization used in this study

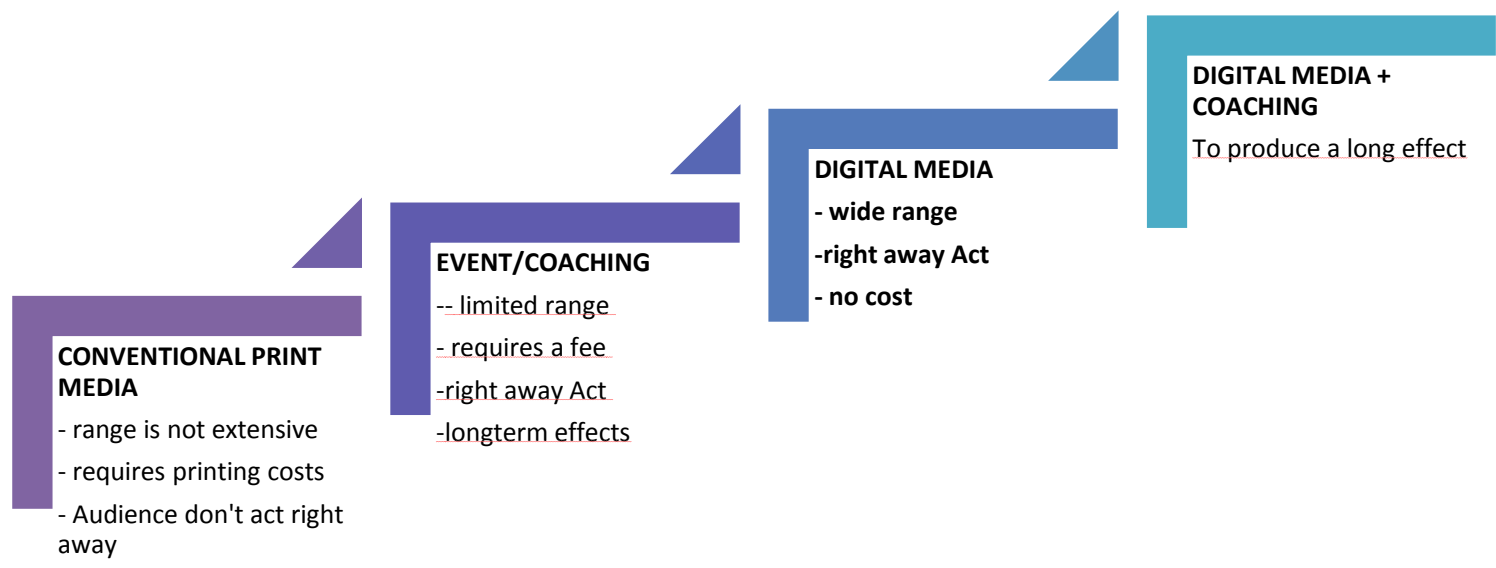

Fig 6. Comparison of the use of various types of campaign media

\section{Conclusion}

In campaigning online consultation website, there are many method or media that we can choose. Conventional print media has it limitation such as the range is not extensive, require printing cost, and audience don.t act right away. Event or coaching session is limited in range, more expensive but it can lead right away action. The most ideal campaign method is elaborating digital media and coaching.

\section{Reference}

[1] Amalia, I. (2014). 7 Kriteria website yang baik, retrieved 15 Oktober 2019 from https://sites.google.com/site/buatwebsite99/7-kriteria-website-yang-baik

[3] Kamis, D.Y. (2016). Bagaimana caranya melapor di Lapor.go.id, retrieved 15 Oktober 2019 from https://www.pikiran-rakyat.com/bandungraya/2016/12/08/bagaimana-cara-melapor-di-laporgoid-387634 
[3] Setyanti, E.P. (2015) Beroperasi sejak 2008 Klikdokter akhirnya miliki aplikasi, retrieved 15 Oktober 2019 from https://id.techinasia.com/aplikasi-mobileklikdokter

[4] Darwis, R. (2017). Membangun Desain dan Model Action research Dalam Studi dan Aksi Pemberdayaan Masyarakat. Komunika, 10(1), 142-150 DOI: 10.24090/komunika.v10i1.869

[5] Mirawati, I. (2016). Media Konsultasi Online Sebagai Alternatif Upaya Penanganan Masalah Remaja. Edulib, 5(1), 90-101. https://doi.org/10.17509/edulib.v5i1.2306

[6] Mirawati, I., Sugiana, D., \& Wirakusumah, T. K. (2019). Online Consulting Mobile Application For Teens In Indonesia : Users Perspective. 8(09), 18561859. 